\title{
Developmental Results of a Vaccine against Salmonella-Induced Equine Abortion
}

\author{
M. P. Neustroev ${ }^{a}$ * and S. G. Petrova ${ }^{a}$ \\ ${ }^{a}$ Safronov Yakut Research Institute of Agriculture, Yakutsk, Sakha Republic, 677001 Russia \\ *e-mail:mneyc@mail.ru \\ Received March 23, 2020; revised May 15, 2020; accepted May 18, 2020
}

\begin{abstract}
An inactivated vaccine based on the Sal. abortus equi BN-12 strain with the Bac. subtilis TNP-3 strain filtrate used as immunomodulator has been developed in order to prevent salmonella-induced equine abortion. Preclinical and clinical trials with the white mice and the horses, respectively, are carried out. The lack of toxicity is proven. The vaccine immunogenicity for mouse and mare models comprised 90 and $100 \%$, respectively. The industrial vaccine tests showed that the industrial output of foals increased by $13.8 \%$ after immunization. Cost-effectiveness of the vaccine used with the Bac. subtilis TNP-3 strain filtrate comprised 14.1 rubles per 1 ruble of costs, which was 1.8 -fold greater when compared to the vaccine used with a polyribonate medicine. It is ascertained that administration of the inactivated vaccine with the Bac. subtilis TNP-3 strain is an effective method to prevent infectious abortion. Scientific and technical documentation is developed based on the survey results in order to submit it for approval to the Rosselkhoznadzor Federal Service for Veterinary and Phytosanitary Surveillance. The instruction is compliant with the approved use. The registration certificate (71-1-10.19-4495 no. PVR-1-1-.6/01631, as of June 10, 2019) has been issued.
\end{abstract}

Keywords: salmonella-induced abortion, vaccine, toxicity, immunogenicity

DOI: $10.3103 / \mathrm{S} 1068367420050158$

\section{INTRODUCTION}

Salmonella-induced equine abortion is most common in the Asian and African countries, while some cases are reported from European countries, the United States, and Argentina [1-4]. A high mortality rate caused by Sal. abortus equi was recorded in Italy [5]. The abortions associated with viral and bacterial infections caused by the rhinovirus and the salmonella agents of equine abortions are most severe [6]. Mixed infections are especially severe in the young horses, and the mortality rate may reach $22 \%$ [7]. Salmonella carriage among the healthy animals is proven [8-9].

Immunization through vaccination is the most effective method to prevent salmonellosis in horses. B.A. Matvienko et al. [10] developed the dry-powder TRE-841 live rabies vaccine used in Kazakhstan. Complex immunization through live vaccines was suggested to prevent rhinovirus pneumonia and salmonella-induced abortion [11-13]. At present, TOO "KazNIVI" Kazakh Research Veterinary Institute produces the live attenuated vaccine against salmonella-induced abortion in mares that is based on the B-0147 Sal. abortus equi strain [14].

An inactivated vaccine against the salmonellainduced equine abortion, which has been developed by the Yakut Research Institute of Agriculture jointly with the Virology Department, All-Russia Research
Institute of Experimental Veterinary, is used in the stud farming systems in Russia [15]. However, its high price caused by polyribonat modulator restrains the use of the vaccine. Moreover, the polyribonat registration date is expired. The necessity for developing prevention means for stopping the spread of new viral infections, including COVID-19, is amplified. The information on the spread of coronavirus among the horses in Colorado State (United States) has appeared [16].

The objective of the surveys was to develop and test the ecologically safe and effective vaccine product for specific prevention of the salmonella-induced equine abortion.

\section{EXPERIMENTAL}

The survey was carried out at the Veterinary Biotechnology Laboratory, Safronov Yakut Research Institute of Agriculture, along with TOO "KhotuBakt" Science Production Center and the horse stud farms in the Sakha Republic (Yakutia).

The Sal. abortus equi BN-12 strain stored at the All-Russia State Research Institute for Control, Standardization, and Certification of Veterinary Preparations was used in order to develop a vaccine against the salmonella-induced equine abortion. The Bac. subtilis TNP-3 strain-based culture liquid (CL or filtrate) stored at the All-Russia State Research Institute for 
Control, Standardization, and Certification of Veterinary Preparations (February 6, 2001) was used in the vaccine's composition.

The analysis of vaccine toxicity after a single administration of injection through the abdomen to nonpedigreed white mice was performed according to the "Sanitary Regulations SP 3.3.2.561-96" (affirmed by Decree no. 33 of October 31, 1996, RF State Sanitary and Epidemiological Surveillance Service). In order to perform the experiment, 11-18-g mice were divided into three groups by the analog design principle. The Bac. subtilis TNP-3 liquid, the vaccine, and the distilled water were administered to the animals in groups one, two, and three (control), respectively. The preparations were injected at a dose of $1 \mathrm{~mL}$ into each in abdomen on an empty stomach in the morning. Clinical observations were carried out for 7 subsequent days, which was followed by killing the animals with alcohol ether in order to carry out the anatomical pathology tests. The anatomical pathology testing was performed according to the common methods.

In order to analyze the vaccine toxicity for the mares (allocated by four animals), the vaccine at doses of $2 \mathrm{~mL}, 3 \mathrm{~mL}$, and $6 \mathrm{~mL}$ was administered with an intramuscular injection in the area of the neck of each of the horses. Clinical observation was carried out for 1 month.

In order to study the stress-related immune changes, the white mice were allocated into three groups of 20 animals each. The animals of group one were immunized with the inactivated vaccine used with the culture liquid containing the Bac. subtilis strain at a dose of $0.2 \mathrm{~mL}$. The animals of group two were subcutaneously injected with the inactivated vaccine used with the polyribonat modulator at a dose of $0.2 \mathrm{~mL}$ in the area of the animals' dorsal side. The animals of group three (control) were not administered any preparation. In 14 days after immunization, the mice were infected with a diurnal culture of a pathogen strain.

In order to analyze the vaccine-induced immune parameters, three groups of 20 mares each in the horse stud section on the "Pokrovskoe" Experimental Farm were formed in November-December 2015. The animals of group one were treated with the inactivated vaccine containing the Bac. subtilis strain. The animals of group two were treated with the inactivated vaccine containing the polyribonate. The animals of (control) group three were not vaccinated. The preparations at a dose of $2 \mathrm{~mL}$ were administered with intramuscular injection in the upper third area of the neck. Three infoal mares from each of the groups were sampled to infect them with the Sal. abortus equi pathogen culture at the minimum infectious dose 30 days after immunization. Clinical observations for the animals were carried out.

The 219 mares at 4-5 months of gestation were sampled among the two stud sections on the
"Pokrodskoe" experimental farm in November 2016 to test them with the inactivated vaccine. The mares were treated with the "Ivomek" preparation for deworming prior to the experiment. The animals were allocated into three groups. The animals of groups one and two were treated with the inactivated vaccine containing the polyribonate and the Bac. subtilis TNP-3 strain, respectively, while the animals in (control) group three were not injected with the vaccine.

The industrial tests for the vaccine were carried out on the farms under the adverse effects of salmonellainduced equine abortion in Yakutia. Vaccine testing and developing the scientific and technical documentation were performed according to the "Medicinal Product Circulation" Federal Law no. 61-FZ of April 12, 2010, and Order no. 430 of August 22, 2017, the Ministry of Agriculture. The digital material is processed in the form of biometrics.

\section{RESULTS AND DISCUSSION}

The body's condition in the white mice during the experiment was generally satisfactory. Motion activity and responses to the external irritants remained common. The appetite was not lost. The hair coat was smooth. The texture of mouse droppings did not change. At the end of the experiment, the body weight gain in the mice of groups one, two, and three comprised 2.01, 2.6, and $1.4 \mathrm{~g}$, respectively.

Anatomical pathology testing the dead white mice of the experimental and control groups did not reveal any organ or tissue pathology. The organ structures were not affected. According to the histological analysis, acute venous stasis in the parenchymal regions and the pulmonary edema were recorded. The pattern of changes was typical for the postmortem changes after asphyxia. Changes in the gastric mucosa in the experimental mice were typical for gastritis that occurred in response to the preparation administration. The histology of the parenchymal organs was unchanged.

The outcomes of the observations for the vaccinated mares could sometimes indicate a swell of pasty consistency at the injection site, which usually lasted for 2-4 days. For the whole period of observations, no refusal of mice to take forage and no symptom indicating depression were revealed.

After infection of the immunized white mice with the virulent culture, two mice, four mice, and 18 mice from groups one, two, and three (control), respectively, died.

No abortion was revealed in the vaccinated mares of groups one and two after infection. Unvaccinated mares of group three were aborted after infection. The Sal. abortus equi pathogenic agent was isolated in the aborted fetuses.

Biochemical profile of mare blood tests showed that there was no change in the levels of total protein and its fractions on the 30th and 90th days after vacci- 
Table 1. Industrial testing the inactivated vaccine based on Bac. Subtilis strain against salmonella abortion in horses

\begin{tabular}{|c|c|c|c|c|c|c|}
\hline Farm, group & Vaccine type & $\begin{array}{l}\text { Number } \\
\text { of heads }\end{array}$ & \begin{tabular}{|c|} 
Produced \\
offspring, \\
heads
\end{tabular} & $\begin{array}{l}\text { Recorded } \\
\text { abortions }\end{array}$ & \begin{tabular}{|c|} 
Abortion \\
of Salmonella \\
infection etiology
\end{tabular} & $\begin{array}{c}\text { Industrial } \\
\text { output } \\
\text { of foals, \% }\end{array}$ \\
\hline $\begin{array}{l}\text { "Nemyugyuntsy", } \\
\text { group one }\end{array}$ & Vaccine + Poliribonat medicine & 101 & 75 & 19 & - & 74.2 \\
\hline $\begin{array}{l}\text { "Nemyugyuntsy", } \\
\text { group two }\end{array}$ & Vaccine + Bac. subtilis & 53 & 44 & - & - & 83.0 \\
\hline $\begin{array}{l}\text { "Nemyugyuntsy", } \\
\text { group three }\end{array}$ & - & 65 & 45 & 11 & 3 & 69.2 \\
\hline $\begin{array}{l}\text { Taatta ulus } \\
\text { Including }\end{array}$ & & 370 & 186 & - & - & 50.2 \\
\hline "Taatta" stud farm & Vaccine + Bac. subtilis & 234 & 101 & - & - & 43.2 \\
\hline "Kordugen" stud farm & & 36 & 27 & - & - & 75.0 \\
\hline "Pobeda" stud farm & & 100 & 58 & - & - & 58.0 \\
\hline Yakutsk suburbs & Vaccine + Bac. subtilis & 124 & 88 & - & - & 70.9 \\
\hline $\begin{array}{l}\text { Megin-Kangalassy } \\
\text { ulus }\end{array}$ & Vaccine + Bac. subtilis & 675 & 327 & - & - & 48.4 \\
\hline
\end{tabular}

nation. In addition, insignificantly increased alpha globulin levels and decreased gamma globulin levels as the fractions of total protein were recorded in the mares of experimental group one. The increased levels of total protein and its albumin and gamma globulin fractions was recorded in the animals of experimental groups one and two on the 150th day after vaccination. This period coincides with the period of maximum synthesis of agglutinating antibodies.

The outcomes of the industrial tests carried out on the "Nemyugyuntsy" farm have proven that administration of the inactivated Bac. subtilis TNP-3 strain vaccine against salmonella-induced equine abortion is an effective method to prevent infectious abortions since it contributes to a $13.8 \%$ increase in the industrial output of foals (Table 1). In the animals of group one, 19 abortions were registered; however, salmonellosis etiology was not determined. In the control group, the agent of salmonellosis causing equin abortion was isolated from three samples of 11 abortions. The industrial tests were continued on the farms in the "Taatta" and Megin-Kangalassy districts or raions known as uluses and the Yakutsk suburbs, where 1169 in-foal mares were vaccinated. The industrial output of foals comprised 58.0,70.9, and $48.4 \%$, which is significantly higher than the values for the previous years, which varied at the level of $34.0-44.0 \%$.

The culture liquid containing the Bac. subtilis TNP-3 strain and the vaccine against salmonellainduced equine abortion used with filtrate do not affect the body condition, do not cause any allergic reactions and pathological changes in organs and tissues, and have no toxic effect on the organisms of laboratory and target animals.

The preclinical tests with the white mice and the industrial tests with the horses have proven that the inactivated Bac. subtilis TNP-3 strain vaccine against salmonella-induced equine abortion is an effective method to prevent infectious abortions.

The cost-effectiveness of the vaccine used with polyribonat comprises 7.8 rubles per 1 ruble of costs. The cost-effectiveness of the vaccine used with the culture filtrate of Bac. subtilis TNP-3 becomes 1.8fold greater, comprising 14.1 rubles per 1 ruble of costs.

It should be noted that the previous surveys have determined that the use of live vaccines against salmonella-induced abortion and pneumonia caused by rhinoviruses is not reasonable because of the extreme climate environments for stud horses kept in Yakutia. The vaccine developed by the authors is not inferior to the live vaccines proposed in Kazakhstan in the effectiveness in the epizootic situations [14]. Therefore, the method developed by the authors for specific prevention of the salmonella-induced equine abortion with the inactivated vaccine used with the culture liquid based on the Bac. subtilis TNP-3 strain is a cost-effective measure that should be recommended for widespread adoption in the stud farming systems.

\section{CONCLUSIONS}

The authors consider that the high effectiveness of the inactivated vaccine may be explained by both the antigen activity of the vaccine strain and the immunomodulatory component represented by the culture liquid (filtrate) of the Bac. subtilis TNP-3 strain. The probability to use the probiotics and the other biologically active substances as immunomodulators within animal vaccination against brucellosis [17], cow salmonellosis [18], and arctic fox salmonellosis [19] is ascertained. The probability of using the Bac. subtilis 
TNP-3 strain filtrate as a modulator to develop the inactivated vaccine against equine pneumonia caused by rhinoviruses has been proven. The Bac. subtilis TNP-3 strain may induce the interferon synthesis and stimulate immunogenicity of inactivated bacterial and viral vaccines $[16,20]$.

Scientific and technical documentation has been developed based on the survey results to submit for approval to the "Rosselkhoznadzor" Federal Service for Veterinary and Phytosanitary Surveillance. The instruction is compliant with the approved use. A registration certificate (71-1-10.19-4495 no. PVR-1-1-.6/01631 of June 10, 2019) has been issued.

\section{COMPLIANCE WITH ETHICAL STANDARDS}

Conflict of interest. The authors declare that they have no conflict of interest.

Statement of welfare of animals. All applicable international, national, and/or institutional guidelines for the care and use of animals were followed. The article does not concern any researches using animals as objects.

\section{REFERENCES}

1. Bustos, C.P., Gallardo, J., Retamar, G., Lanza, N.S., Falzoni, E., Caffer, M.I., Picos, J., Munoz, A.J., Perez, A., Moras, E.V., Mesplet, M., and Guida, N., Salmonella enterica serovar Abortusequi as an emergent pathogen causing equine abortion in Argentine, J. Equine Vet. Sci., 2016, no. 39, pp. 58-59.

2. Llorente, L.A., Ivanissevich, A., Camina, S., Marco, L., Vissani, A., Olguin, C., Herrera, M., and Barrandeguy, M., Occurrence of multiple abortions due to Salmonella enterica serovar Abortusequi infection, J. Equine Vet. Sci., 2016, no. 39, p. 58.

3. Marenzoni, M.L., Causes of equine abortion, stillbirth and neonatal death in central Italy, Vet. Rec., 2012, vol. 170, p. 262.

4. Rodriguez, A., Prevalence of Salmonella in diverse environmental farm samples, J. Food Prot., 2006, no. 69, pp. 2576-2580.

5. Grandolfo, E., Parisi, A., Ricci, A., Lorusso, E., de Siena, R., Trotta, A., Buonavoglia, D., Martella, V., and Corrente, M., High mortality in foals associated with Salmonella enterica subsp. enterica Abortusequi infection in Italy, J. Vet. Diagn. Invest., 2018, vol. 30, no. 3, pp. 483-485.

6. Yurov, K.P., Infektsionnye bolezni loshadei (Equine Infectious Diseases), Moscow: Rosagropromizdat, 2000.

7. Neustroev, M.P. and Petrova, S.G., Features of the epizootology of Salmonella abortion of horses in Yakutia, Sel'skokhozyaistvennye nauki i agropromyshlennyi kompleks na rubezhe vekov: Sbornik materialov XX mezhdunarodnoi nauchno-prakticheskoi konferentsii (Agricultural Sciences and Agro-Industrial Complex at the Turn of the Century: Proc. XX Int. Sci.-Pract. Conf.), Novosibirsk, 2017, pp. 93-97.

8. Litvinova, Z.A., Pathological manifestation and treatment of thrombohemorrhagic syndrome in Salmonel- losis in calves, Dal'nevost. Agrar. Vestn., 2016, no. 2, pp. 56-62.

9. Swerczek, T.W., Identifying the bacterial causes of abortion inmares, Vet. Med., 1991, no. 86, pp. 1210-1216.

10. Matvienko, B.A., Vsevolodov, B.P., and Kulyashbekova, R.K., Characteristics of a live dry vaccine against paratyphoid abortion in mares from strain E-841, Vestn. S-kh. Nauki, 1973, no. 4, pp. 107-110.

11. Akhmetsadykov, N.N., Complex immunoprophylaxis of rhinopneumonia and Salmonella abortion in mares with live vaccines, Extended Abstract of Cand. Sci. (Vet.) Dissertation, Alma-Ata, 1988.

12. Akhmetsadykov, N.N. and Biyashev, K.B., Biological and immunogenic properties of vaccine strains against Salmonella abortion and equine rhinopneumonia, in Diagnostika, lechenie $i$ profilaktika infektsionnykh boleznei zhivotnykh Kazakhstana (Diagnostics, Treatment, and Prevention of Infectious Animal Diseases in Kazakhstan), Alma-Ata, 1989, pp. 94-99.

13. Yurov, K.P., Infektsionnye bolezni loshadei (Equine Infectious Diseases), Moscow: Rosagropromizdat, 1991, pp. 114-118.

14. Musaeva, A.K. and Egorova, N.N., Specific prevention of Salmonella abortion in mares in Kazakhstan, Agrarnaya nauka - sel'skokhozyaistvennomu proizvodstvu Sibiri, Kazakhstana, Mongolii, Belorussii i Bolgarii: Materialy XXI Mezhdunarodnoi nauchno-prakticheskoi konferentsii (Novosibirsk 16-17 noyabrya 2017 g.) (Agricultural Science to Agricultural Production in Siberia, Kazakhstan, Mongolia, Belarus, and Bulgaria: Proc. XXI Int. Sci.-Pract. Conf. (Novosibirsk, November 16-17, 2017)), Novosibirsk, 2018, pp. 197-198.

15. Neustroev, M.P., Tarabukina, N.P., and Petrova, S.G., A method for enhancing the efficacy of vaccination and reducing the frequency of infectious abortion in herd horse breeding, Russ. Agric. Sci., 2019, vol. 45, pp. 209-211.

16. Manship, A.J., Bliklager, A.T., and Elfenbein, J.R., Disease features of equine coronavirus and enteric salmonellosis are similar in horses, J. Vet. Med., 2019, vol. 33, no. 2, pp. 912-917.

17. L'vova, O.V., Oshchepkov, V.G., Popova, T.G., Bronnikov, V.S., and Gus'kova, T.V., Possibility of using probiotics when vaccinating animals with various antibrucellosis vaccines, Materialy shestoi mezhregional'noi konferentsii, posvyashchennoi 85-letiyu SibNIVI VNIITBZh (g. Omsk, 7-8 dekabrya 2007g) (Proc. Sixth Interreg. Conference dedicated to the 85th anniversary of SibNIVI VNIITBZh (Omsk, December 7-8, 2007)), Novosibirsk, 2007, no. 2, pp. 111-114.

18. Shakhov, A.G., Mas'yanov, Yu.N., Brigadirov, Yu.N., Pershina, S.I., Biryukova, M.V., Zolotarev, A.I., Kardashov, A.M., and Batishcheva, E.V., The use of immunomodulators in the vaccination of animals against salmonellosis, Veterinariya, 2006, no. 6, pp. 21-26.

19. Solov'eva, A.S., Ovsyannikov, Yu.S., Domskii, I.A., and Bel'tyukova, Z.N., The use of subalin in the vaccination of polar fox puppies against salmonellosis, Vet. Med., 2011, nos. 3-4, pp. 124-126.

20. Osmaev, I.A., Yurov, K.P., and Neustroev, M.P., Immunomodulating properties of endogenous interferon in calves, Veterinariya, 2007, no. 1, pp. 11-13.

Translated by O. Zhiryakova 